\title{
Enhanced Eryptosis Following Exposure to Dolutegravir
}

\author{
Abdulla Al Mamun Bhuyan ${ }^{a}$ Elena Signoretto ${ }^{a, b} \quad$ Rosi Bissinger ${ }^{a} \quad$ Florian Lang ${ }^{a}$ \\ aDepartments of Cardiology, Vascular Medicine and Physiology, Eberhard-Karls-University of \\ Tuebingen, Tuebingen, Germany; ${ }^{b}$ Department of Pharmacological and Biomolecular Sciences, \\ Università degli Studi di Milano, Milano, Italy
}

Key Words

Phosphatidylserine $\cdot$ Cell volume $\bullet$ Eryptosis $\bullet$ Ceramide $\bullet$ Calcium $•$ Oxidative stress

\begin{abstract}
Background/Aims: The viral integrase enzyme inhibitor dolutegravir is utilized for the treatment of immunodeficiency virus (HIV) infection. Knowledge on cytotoxicity of dolutegravir is limited. The present study thus explored, whether dolutegravir is able to trigger suicidal erythrocyte death or eryptosis, which is characterized by cell shrinkage and cell membrane scrambling with phosphatidylserine translocation to the erythrocyte surface. Cellular mechanisms involved in the triggering of eryptosis include increase of cytosolic $\mathrm{Ca}^{2+}$ activity $\left(\left[\mathrm{Ca}^{2+}\right]_{\mathrm{i}}\right)$, oxidative stress, ceramide, and activation of protein kinase $\mathrm{C}$, p38 kinase, casein kinase, and caspases. The present study explored, whether Dolutegravir induces eryptosis and, if so, to gain insight into cellular mechanisms involved. Methods: Utilizing flow cytometry, phosphatidylserine exposure at the cell surface was estimated from annexin-V-binding, cell volume from forward scatter, $\left[\mathrm{Ca}^{2+}\right]_{i}$ from Fluo3-fluorescence, ROS formation from DCFDA dependent fluorescence, and ceramide abundance utilizing specific antibodies. Hemolysis was quantified from haemoglobin concentration in the supernatant. Results: A 48 hours exposure of human erythrocytes to dolutegravir significantly increased the percentage of annexin- $V$ binding cells $(\geq 4.8 \mu \mathrm{M})$, significantly increased hemolysis $(19.1 \mu \mathrm{M})$, but did not significantly modify forward scatter. Dolutegravir significantly increased Fluo3-fluorescence $(\geq 4.8 \mu \mathrm{M})$, DCFDA fluorescence $(19.1 \mu \mathrm{M})$ and ceramide abundance $(19.1 \mu \mathrm{M})$. The effect of dolutegravir on annexin-V-binding was significantly blunted by removal of extracellular $\mathrm{Ca}^{2+}$, but was not significantly modified by protein kinase $C$ inhibitor staurosporine $(1 \mu \mathrm{M})$, p38 kinase inhibitor SB203580 $(2 \mu \mathrm{M})$, casein kinase inhibitor D4476 $(10 \mu \mathrm{M})$ or pancaspase inhibitor zVAD (10 $\mu \mathrm{M})$. Conclusions: Dolutegravir triggers cell shrinkage and phospholipid scrambling of the erythrocyte cell membrane, an effect at least in part due to $\mathrm{Ca}^{2+}$ entry, ceramide formation and oxidative stress.

\section{Introduction}

Dolutegravir, a viral integrase enzyme inhibitor [1-24], is effective in the treatment of human immunodeficiency virus (HIV) infection [1-14, 17, 19-27]. Side effects include

Florian Lang

KARGER 
inhibition of the organic cation transporter 2 with decrease of creatinine clearance, diarrhea, headache, nausea, and insomnia [4, 17, 19, 20, 28].

Little is known about cytotoxicity of dolutegravir. A wide variety of xenobiotics [29-68] including antiviral drugs [69, 70] trigger eryptosis [56], the suicidal death of erythrocytes characterized by cell shrinkage [71] and cell membrane scrambling with phosphatidylserine translocation to the cell surface [56]. Induction of eryptosis has thus proven a sensitive measure of cytotoxicity [56]. Cellular mechanisms leading to eryptosis include increase of cytosolic $\mathrm{Ca}^{2+}$ activity $\left(\left[\mathrm{Ca}^{2+}\right]_{\mathrm{i}}\right)[56]$, ceramide [72], oxidative stress [56, 73, 74], energy depletion [56], caspases [56, 75, 76], casein kinase $1 \alpha$, Janus-activated kinase JAK3, protein kinase C, and p38 kinase [56]. Cellular mechanisms counteracting eryptosis include AMP activated kinase AMPK, cGMP-dependent protein kinase, PAK2 kinase [56], cyclin-dependent kinase CDK4 [77], mitogen- and stress-activated kinase MSK1/2 [78], and sorafenib/ sunitinib sensitive kinases [56].

The present study tested, whether dolutegravir stimulates eryptosis. To this end, human erythrocytes from healthy volunteers were exposed to dolutegravir and phosphatidylserine surface abundance, cell volume, $\left[\mathrm{Ca}^{2+}\right]_{\mathrm{i}}$, ROS formation, and ceramide abundance determined by flow cytometry.

\section{Materials and Methods}

Erythrocytes, solutions and chemicals

Fresh Li-Heparin-anticoagulated blood samples were kindly provided by the blood bank of the University of Tübingen. The study is approved by the ethics committee of the University of Tübingen (184/2003 V). The blood was centrifuged at $120 \mathrm{xg}$ for $20 \mathrm{~min}$ at $21^{\circ} \mathrm{C}$ and the platelets and leukocytes-containing supernatant was disposed. Erythrocytes were incubated in vitro at a hematocrit of $0.4 \%$ in Ringer solution containing (in $\mathrm{mM}) 125 \mathrm{NaCl}, 5 \mathrm{KCl}, 1 \mathrm{MgSO}_{4}, 32 \mathrm{~N}$-2-hydroxyethylpiperazine-N-2-ethanesulfonic acid (HEPES; pH 7.4), 5 glucose, $1 \mathrm{CaCl}_{2}$, at $37^{\circ} \mathrm{C}$ for 48 hours. Where indicated, erythrocytes were exposed for 48 hours to dolutegravir (MedChem Express, Princeton, USA). To test for an involvement of kinases, erythrocytes were exposed for 48 hours to a combination of dolutegravir and p38 kinase inhibitor SB203580 (Tocris bioscience, Bristol, UK), casein kinase inhibitor D4476 (Tocris bioscience, Bristol, UK) and protein kinase C inhibitor staurosporine (Enzo Life Sciences, Lörrach, Germany). The putative involvement of caspases was tested by the use of the pancaspase inhibitor zVAD (Enzo Life Sciences, Lörrach, Germany).

\section{Annexin-V-binding and forward scatter}

After incubation under the respective experimental condition, a $150 \mu \mathrm{l}$ cell suspension was washed in Ringer solution containing $5 \mathrm{mM} \mathrm{CaCl}_{2}$ and then stained with Annexin-V-FITC (1:200 dilution; ImmunoTools, Friesoythe, Germany) in this solution at $37^{\circ} \mathrm{C}$ for 15 min under protection from light. The annexin-Vabundance at the erythrocyte surface was subsequently determined on a FACS Calibur (BD, Heidelberg, Germany). Annexin-V-binding was measured with an excitation wavelength of $488 \mathrm{~nm}$ and an emission wavelength of $530 \mathrm{~nm}$. A marker (M1) was placed to set an arbitrary threshold between annexin-V-binding cells and control cells. The same threshold was used for untreated and dolutegravir treated erythrocytes. A dot plot of forward scatter (FSC) vs. side scatter (SSC) was set to linear scale for both parameters. The threshold of forward scatter was set at the default value of " 52 ".

\section{Hemolysis}

Following incubation, the erythrocyte suspension was centrifuged for 3 min at $1600 \mathrm{rpm}, 4^{\circ} \mathrm{C}$, and the supernatants were harvested. As a measure of hemolysis, the hemoglobin $(\mathrm{Hb})$ concentration of the supernatants was determined photometrically at $405 \mathrm{~nm}$. The absorption of the supernatant of erythrocytes lysed in distilled water was defined as $100 \%$ hemolysis.

Intracellular $\mathrm{Ca}^{2+}$

After incubation, erythrocytes were washed in Ringer solution and loaded with Fluo-3/AM (Biotium, Hayward, USA) in Ringer solution containing $5 \mathrm{mM} \mathrm{CaCl}_{2}$ and $5 \mu \mathrm{M}$ Fluo-3/AM. The cells were incubated 
at $37^{\circ} \mathrm{C}$ for $30 \mathrm{~min} . \mathrm{Ca}^{2+}$-dependent fluorescence intensity was measured with an excitation wavelength of $488 \mathrm{~nm}$ and an emission wavelength of $530 \mathrm{~nm}$ on a FACS Calibur. Afterwards, the geomean of the $\mathrm{Ca}^{2+}$ dependent fluorescence was determined.

Reactive oxygen species (ROS)

Oxidative stress was determined utilizing 2',7'-dichlorodihydrofluorescein diacetate (DCFDA). After incubation, a $150 \mu$ l suspension of erythrocytes was washed in Ringer solution and stained with DCFDA (Sigma, Schnelldorf, Germany) in Ringer solution containing DCFDA at a final concentration of $10 \mu \mathrm{M}$. Erythrocytes were incubated at $37^{\circ} \mathrm{C}$ for $30 \mathrm{~min}$ in the dark and washed two times in Ringer solution. The DCFDA-loaded erythrocytes were resuspended in $200 \mu \mathrm{l}$ Ringer solution and ROS-dependent fluorescence intensity was measured at an excitation wavelength of $488 \mathrm{~nm}$ and an emission wavelength of $530 \mathrm{~nm}$ on a FACS Calibur (BD). Subsequently, the geomean of the DCFDA dependent fluorescence was determined.

Ceramide abundance

For the determination of ceramide, a monoclonal antibody-based assay was used. To this end, a $100 \mu \mathrm{l}$ suspension of erythrocytes was stained for 1 hour at $37^{\circ} \mathrm{C}$ with $1 \mu \mathrm{g} / \mathrm{ml}$ anti ceramide antibody (clone MID 15B4, Alexis, Grünberg, Germany) in PBS containing 0.1\% bovine serum albumin (BSA) at a dilution of 1:10. The samples were washed twice with PBS-BSA. The cell suspension was subsequently stained for 30 minutes with polyclonal fluorescein isothiocyanate (FITC) conjugated goat anti-mouse IgG and IgM specific antibody (Pharmingen, Hamburg, Germany) diluted 1:50 in PBS-BSA. Unbound secondary antibody was removed by repeated washing with PBS-BSA. The samples were analyzed by flow cytometric analysis with an excitation wavelength of $488 \mathrm{~nm}$ and an emission wavelength of $530 \mathrm{~nm}$. As a control, secondary antibody alone was used. Finally, the geomean of the ceramide-dependent fluorescence was determined.

\section{Statistics}

Data are expressed as arithmetic means \pm SEM. As indicated in the figure legends, statistical analysis was made using ANOVA with Tukey's test as post-test and $t$ test as appropriate. $\mathrm{n}$ denotes the number of different erythrocyte specimens studied. Since different erythrocyte specimens used in distinct experiments are differently susceptible to triggers of eryptosis, the same erythrocyte specimens have been used for control and experimental conditions.

\section{Results}

The present study explored, whether dolutegravir stimulates eryptosis, the suicidal erythrocyte death. A hallmark of eryptosis is phospholipid scrambling of the cell membrane with phosphatidylserine translocation to the cell surface. Phosphatidylserine exposing erythrocytes were identified utilizing annexin-V-binding, as determined by flow cytometry. Prior to measurements, the erythrocytes were incubated for 48 hours in Ringer solution without or with dolutegravir (4.77-19.08 $\mu \mathrm{M})$. As shown in Fig. 1, a 48 hours exposure to dolutegravir increased the percentage of phosphatidylserine exposing erythrocytes, an effect reaching statistical significance at $4.77 \mu \mathrm{M}$ dolutegravir.

Hemoglobin concentration in the supernatant was determined in order to quantify hemolysis. As shown in Fig. 2, a 48 hours exposure to dolutegravir increased the percentage of hemolytic erythrocytes, an effect reaching statistical significance at $19.08 \mu \mathrm{M}$ dolutegravir.

A second hallmark of eryptosis is cell shrinkage. Erythrocyte volume was thus estimated from forward scatter which was determined utilizing flow cytometry. The measurements were again performed after incubation of the erythrocytes for 48 hours in Ringer solution without or with dolutegravir (4.77-19.08 $\mu \mathrm{M})$. As a result, after incubation for 48 hours, the forward scatter was similar in Ringer (515.8 $\pm 6.2, \mathrm{n}=19)$, in DMSO (531.9 $\pm 11.9, \mathrm{n}=19)$, in $4.77 \mu \mathrm{M}$ dolutegravir (528.0 $\pm 10.9, \mathrm{n}=19)$, in $9.54 \mu \mathrm{M}$ dolutegravir $(519.2 \pm 9.5, \mathrm{n}=19)$ and in $19.08 \mu \mathrm{M}$ dolutegravir $(515.6 \pm 8.1, \mathrm{n}=19)$. Thus, dolutegravir did not significantly modify erythrocyte volume. 
Fig. 1. Effect of dolutegravir on phosphatidylserine exposure. A. Original histograms of annexin-Vbinding of erythrocytes following exposure for 48 hours to Ringer solution without (grey area) and with (black line) presence of $19.08 \mu \mathrm{M}$ dolutegravir. B. Arithmetic means \pm SEM ( $n=19)$ of erythrocyte annexin-V-binding following incubation for 48 hours to Ringer solution without (white bar) or with (black bars) dolutegravir (4.77-19.08 $\mu \mathrm{M})$. For comparison, the effect of the solvent DMSO is shown (grey bar $){ }^{* * *}(\mathrm{p}<0.001)$ indicates significant difference from the absence of dolutegravir (ANOVA).

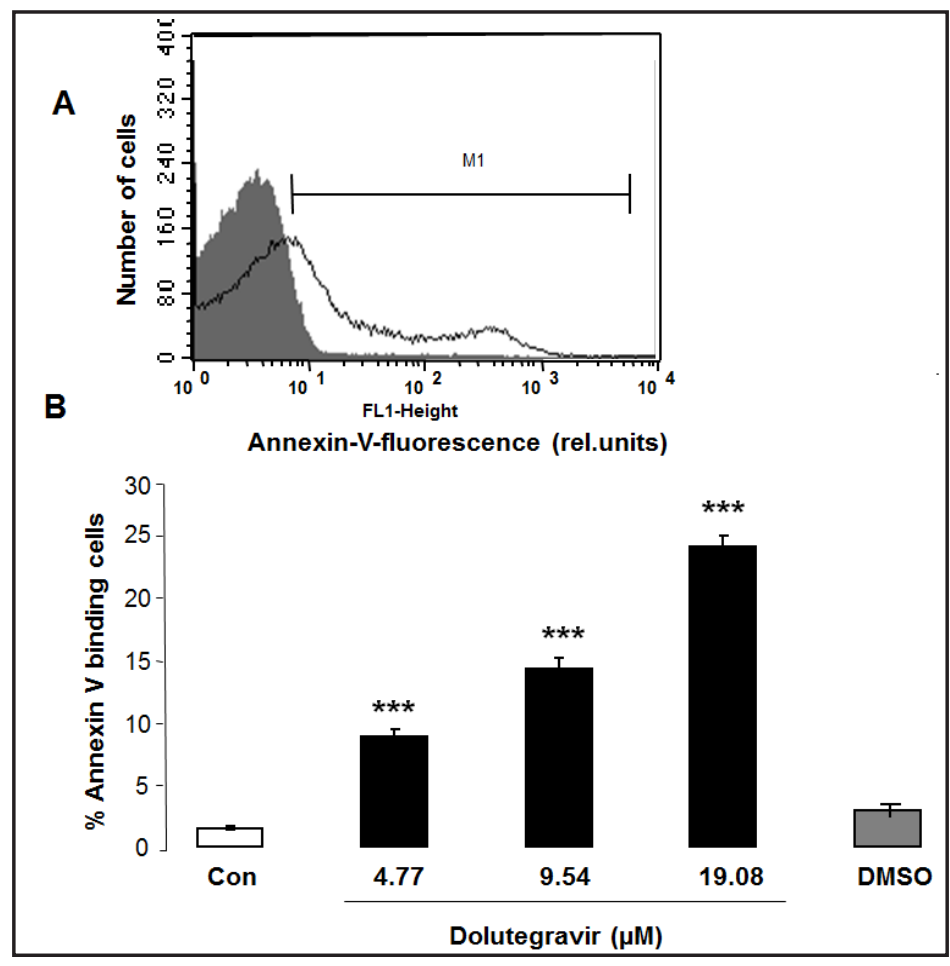

Fig. 2. Effect of Dolutegravir on hemolysis. Arithmetic means \pm SEM $(n=5)$ of the percentage of hemolytic erythrocytes following incubation for 48 hours to Ringer solution without (white bar) or with (black bars) dolutegravir (4.77$19.08 \mu \mathrm{M})$. For comparison, the effect of the solvent DMSO is shown (grey bar). ${ }^{* *}(\mathrm{p}<0.01)$ indicates significant difference from the absence of dolutegravir (ANOVA).

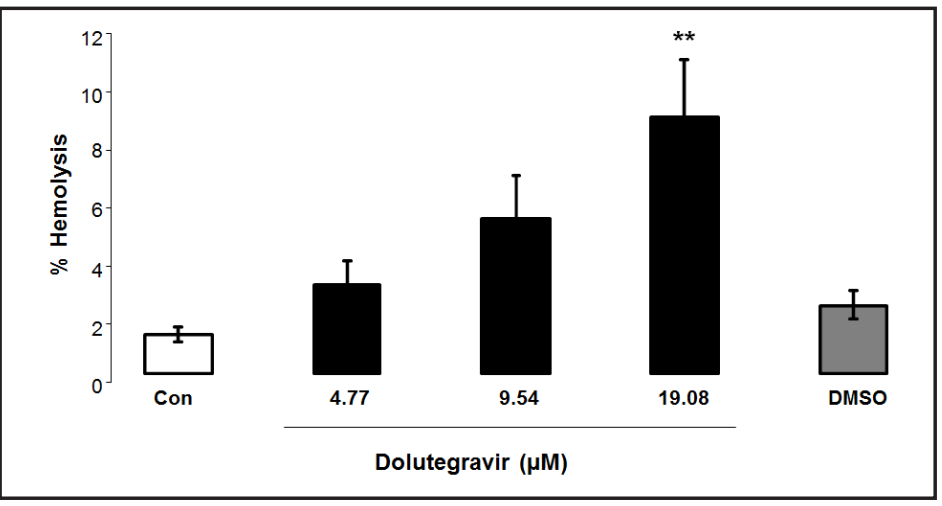

Fluo3 fluorescence was taken as a measure of cytosolic $\mathrm{Ca}^{2+}$ activity $\left(\left[\mathrm{Ca}^{2+}\right]_{\mathrm{j}}\right)$. As illustrated in Fig. 3, following 48 hours incubation, the Fluo3 fluorescence was larger in the presence than in the absence of dolutegravir, a difference reaching statistical significance at $4.77 \mu \mathrm{M}$ dolutegravir concentration.

A next series of experiments explored, whether the dolutegravir-induced cell shrinkage and translocation of phosphatidylserine or erythrocyte shrinkage required entry of extracellular $\mathrm{Ca}^{2+}$. To this end, erythrocytes were incubated for 48 hours in the absence or presence of $19.08 \mu \mathrm{M}$ dolutegravir in the presence or nominal absence of extracellular $\mathrm{Ca}^{2+}$. As illustrated in Fig. 4, removal of extracellular $\mathrm{Ca}^{2+}$ significantly blunted the effect of dolutegravir on the percentage of annexin-V-binding erythrocytes. However, even in the absence of extracellular $\mathrm{Ca}^{2+}$, dolutegravir significantly increased the percentage of annexinV-binding erythrocytes. Thus, dolutegravir-induced cell membrane scrambling was in large part but not fully dependent on entry of extracellular $\mathrm{Ca}^{2+}$.

In order to explore the involvement of kinases in the stimulation of eryptosis by dolutegravir, experiments were repeated in the presence and absence of the respective kinase inhibitors. As a result, the increase of annexin-V-binding erythrocytes following treatment with dolutegravir 
Fig. 3. Effect of Dolutegravir on cytosolic $\mathrm{Ca}^{2+}$ activity. A. Original histograms of Fluo3-fluorescence in erythrocytes following exposure for 48 hours to Ringer solution without (grey area) and with (black line) presence of $19.08 \mu \mathrm{M}$ dolutegravir. B. Arithmetic means \pm SEM $(n=19)$ of erythrocyte Fluo3 fluorescence following incubation for 48 hours to Ringer solution without (white bar) or with (black bars) dolutegravir (4.77-19.08 $\mu \mathrm{M})$. For comparison, the effect of the solvent DMSO is shown (grey bar). $*(p<0.05)$, $* * *(p<0.001)$ indicate significant difference from the absence of dolutegravir (ANOVA).
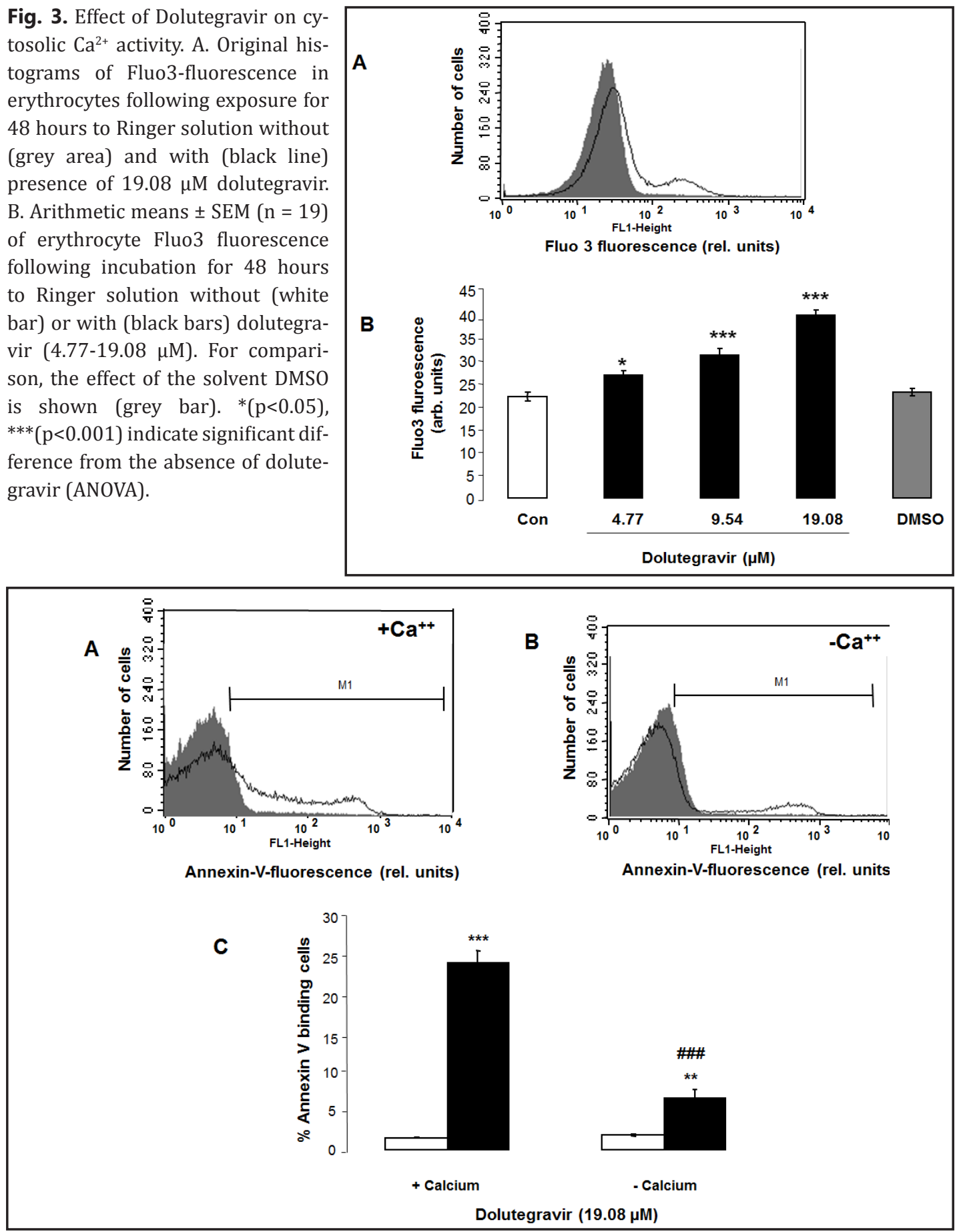

Fig. 4. $\mathrm{Ca}^{2+}$ sensitivity of dolutegravir-induced phosphatidylserine exposure. A,B. Original histograms of annexin-V-binding of erythrocytes following exposure for 48 hours to Ringer solution without (grey area) and with (black line) dolutegravir $(19.08 \mu \mathrm{M})$ in the presence (A) and absence (B) of extracellular $\mathrm{Ca}^{2+}$. C. Arithmetic means \pm SEM $(n=14)$ of annexin-V-binding of erythrocytes after a 48 hours treatment with Ringer solution without (white bars) or with (black bars) dolutegravir $\left(19.08 \mu \mathrm{M}\right.$ ) in the presence (left bars, $+\mathrm{Ca}^{2+}$ ) and absence (right bars, $\left.-\mathrm{Ca}^{2+}\right)$ of $\mathrm{Ca}^{2+} . * *(\mathrm{p}<0.01)$, ${ }^{* * *}(\mathrm{p}<0.001)$ indicate significant difference from the absence of dolutegravir, \#\#\#(p<0.001) indicates significant difference from the presence of $\mathrm{Ca}^{2+}$ (ANOVA).

$(19.08 \mu \mathrm{M})$ was similar in the absence (from $1.9 \pm 0.4 \%[\mathrm{n}=5]$ to $23.0 \pm 2.7 \%$ [n = 5]) and in the presence (from $1.9 \pm 0.3 \%[n=5]$ to $21.8 \pm 1.7 \%[n=5]$ ) of p38 kinase inhibitor SB 203580 


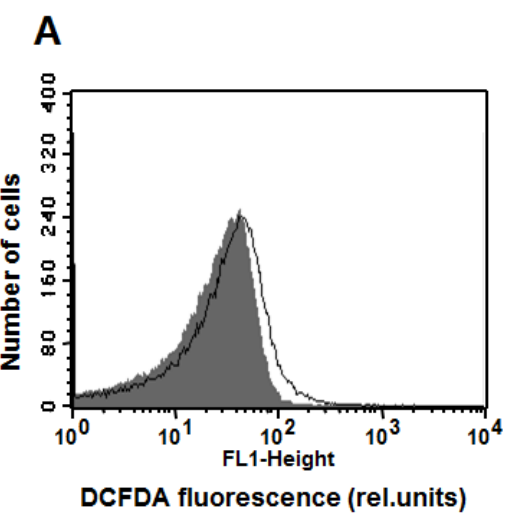

C

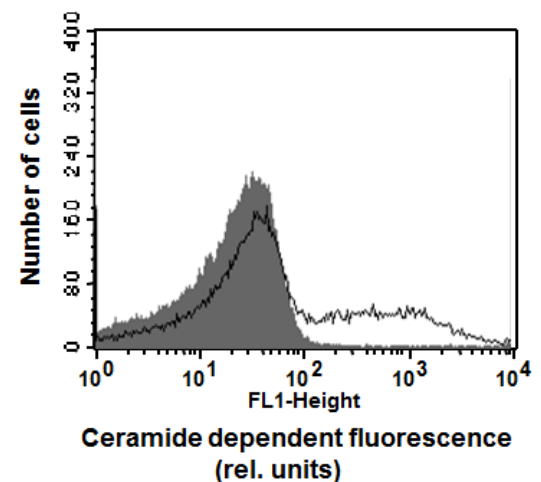

B

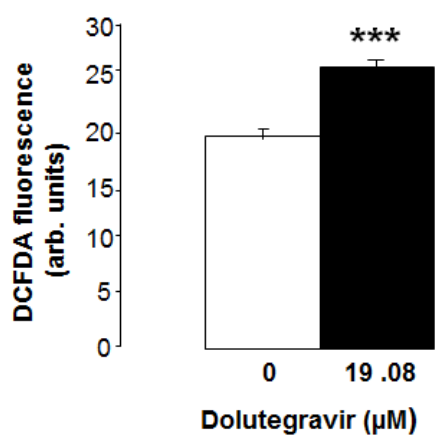

D

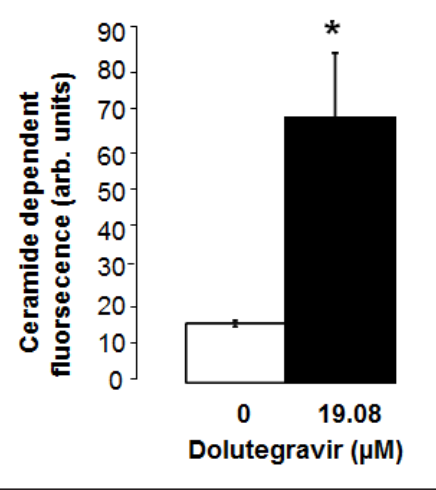

Fig. 5. Effect of dolutegravir on erythrocyte ROS formation and ceramide abundance at the erythrocyte surface. A. Original histograms of DCFDA fluorescence in erythrocytes following exposure for 48 hours to Ringer solution without (grey area) and with (black line) presence of dolutegravir $(19.08 \mu \mathrm{M})$. B. Arithmetic means \pm SEM $(n=10)$ of the DCFDA fluorescence (arbitrary units) in erythrocytes exposed for 48 hours to Ringer solution without (white bar) or with (black bar) dolutegravir $(19.08 \mu \mathrm{M}) .{ }^{* * *}(\mathrm{p}<0.001)$ indicates significant difference from the absence of dolutegravir (unpaired $t$ test). C. Original histograms of ceramide abundance in erythrocytes following exposure for 48 hours to Ringer solution without (grey area) and with (black line) presence of $19.08 \mu \mathrm{M}$ dolutegravir. D. Arithmetic means \pm SEM $(n=6)$ of the ceramide abundance (arbitrary units) in erythrocytes exposed for 48 hours to Ringer solution without (white bar) or with (black bar) presence of $19.08 \mu \mathrm{M}$ dolutegravir. ${ }^{*}(\mathrm{p}<0.05)$ indicates significant difference from the absence of dolutegravir (unpaired $t$ test).

$(2 \mu \mathrm{M})$. The increase of annexin-V-binding erythrocytes following treatment with dolutegravir $(19.08 \mu \mathrm{M})$ was further similar in the absence (from $1.5 \pm 0.2 \%[\mathrm{n}=15]$ to $20.6 \pm 1.8 \%[\mathrm{n}=$ $15])$ and in the presence (from $1.4 \pm 0.1 \%[n=15]$ to $20.7 \pm 1.8 \%[n=15]$ ) of casein kinase inhibitor D4476 (10 $\mu \mathrm{M})$. Moreover, the increase of annexin-V-binding erythrocytes following treatment with dolutegravir $(19.08 \mu \mathrm{M})$ was similar in the absence (from $2.1 \pm 0.5 \%$ [n $=5]$ to $23.1 \pm 2.1 \%[n=5])$ and in the presence (from $6.0 \pm 0.9 \%[n=5]$ to $25.2 \pm 1.7 \%[n=5]$ ) of protein kinase $\mathrm{C}$ inhibitor staurosporine $(1 \mu \mathrm{M})$.

The putative involvement of caspases was tested utilizing pancaspase inhibitor zVAD. As a result, the increase of annexin-V-binding erythrocytes following treatment with dolutegravir $(19.08 \mu \mathrm{M})$ was similar in the absence (from $1.5 \pm 0.2 \%$ [n=14] to $23.2 \pm 1.5 \%$ [n $=14]$ ) and in the presence (from $1.8 \pm 0.2 \%[n=14]$ to $20.9 \pm 1.7 \%[n=14]$ ) of zVAD $(10 \mu M)$.

Eryptosis is further stimulated by oxidative stress. Reactive oxygen species (ROS) was thus quantified utilizing $2^{\prime}, 7^{\prime}$-dichlorodihydrofluorescein diacetate (DCFDA). As illustrated in Fig. 5A,B, the DCFDA fluorescence was significantly higher following exposure to dolutegravir $(19.08 \mu \mathrm{M})$ than in the absence of dolutegravir. 
A further stimulator of eryptosis is ceramide. Ceramide abundance at the erythrocyte surface was thus quantified utilizing specific antibodies. As illustrated in Fig. 5C,D, the ceramide abundance was significantly higher following exposure to dolutegravir $(19.08 \mu \mathrm{M})$ than in the absence of dolutegravir.

\section{Discussion}

The present observations reveal a toxic effect of dolutegravir on erythrocytes. Exposure of erythrocytes drawn from healthy individuals to dolutegravir is followed by cell membrane scrambling with phosphatidylserine translocation to the erythrocyte surface. The concentrations required for the effect are well in the range of reported plasma concentrations encountered following dolutegravir administration in man [28].

The effect of dolutegravir on cell membrane scrambling was paralleled by increase of cytosolic $\mathrm{Ca}^{2+}$ activity $\left(\left[\mathrm{Ca}^{2+}\right]_{\mathrm{i}}\right)$, was in large part blunted by removal of extracellular $\mathrm{Ca}^{2+}$ and was thus partially dependent on $\mathrm{Ca}^{2+}$ entry from the extracellular space. Nevertheless, even in the absence of extracellular $\mathrm{Ca}^{2+}$, dolutegravir stimulated cell membrane scrambling indicating that a small part of cell membrane scrambling did not require an increase of $\left[\mathrm{Ca}^{2+}\right]_{\mathrm{i}}$. Thus, dolutegravir apparently stimulated $\mathrm{Ca}^{2+}$ entry but by the same token sensitized the cell to the scrambling effect of $\mathrm{Ca}^{2+}$. Sensitization of erythrocytes for the scrambling effect of $\mathrm{Ca}^{2+}$ is observed following exposure to ceramide [56]. The triggering of cell membrane scrambling by dolutegravir was indeed paralleled by increase of ceramide abundance. Moreover, dolutegravir triggered eryptosis was paralleled by oxidative stress, a well known stimulator of eryptosis [56]. The effect of dolutegravir did not require the activity of p38 kinase, casein kinase or staurosporine sensitive kinases such as protein kinase $\mathrm{C}$. The dolutegravir induced cell membrane scrambling was further insensitive to the presence of pancaspase inhibitor zVAD. Collectively, $\mathrm{Ca}^{2+}$ entry, ceramide and oxidative stress explain most, if not all the effect of dolutegravir on erythrocyte cell membrane scrambling.

Despite the increase of $\left[\mathrm{Ca}^{2+}\right]_{i}$ dolutegravir did not trigger cell shrinkage. An increase of $\left[\mathrm{Ca}^{2+}\right]_{i}$ was expected to activate $\mathrm{Ca}^{2+}$ sensitive $\mathrm{K}^{+}$channels thus leading to $\mathrm{K}^{+}$exit, cell membrane hyperpolarization, $\mathrm{Cl}^{-}$exit and cellular loss of $\mathrm{KCl}$ with water. The mechanism preventing the cell shrinkage despite the increase of $\left[\mathrm{Ca}^{2+}\right]_{i}$ remained elusive. Potential mechanisms include interference with $\mathrm{Na}^{+} / \mathrm{K}^{+}$ATPase activity with decrease of cellular $\mathrm{K}^{+}$and thus $\mathrm{Ca}^{2+}$ induced hyperpolarization.

Dolutegravir treatment is further followed by hemolysis with release of hemoglobin, which passes the renal glomerular filter, precipitates in the acidic lumen of renal tubules, occludes nephrons and thus may lead to renal failure [79]. As phosphatidylserine exposing erythrocytes are rapidly cleared from circulating blood, eryptosis may prevent hemolysis in vivo by removing the defective erythrocytes prior to hemolysis. Eryptosis may further serve to eliminate erythrocytes infected with the malaria pathogen Plasmodium. Excessive eryptosis may, however, lead to anemia as soon as the loss of erythrocytes surpasses the formation of new erythrocytes by erythropoiesis [56]. Phosphatidylserine exposing erythrocytes further adhere to the vascular wall [80], stimulate blood clotting and trigger thrombosis [81-83], thus impairing microcirculation [72, 81, 84-87]

The sensitivity to dolutegravir may be enhanced in clinical conditions with accelerated eryptosis, such as dehydration [88], hyperphosphatemia [89], chronic kidney disease (CKD) [90-93], hemolytic-uremic syndrome [94], diabetes [95], hepatic failure [96], malignancy [56], sepsis [97], sickle-cell disease [56], beta-thalassemia [56], Hb-C and G6PD-deficiency [56], as well as Wilsons disease [98]. Patients with those conditions may, at least in theory, be particularly sensitive to dolutegravir-induced triggering of anemia and impairment of microcirculation.

In conclusion, dolutegravir triggers erythrocyte cell membrane scrambling, an effect apparently involving $\mathrm{Ca}^{2+}$ entry, oxidative stress and ceramide. 


\section{Cellular Physiology Cell Physiol Biochem 2016;39:639-650

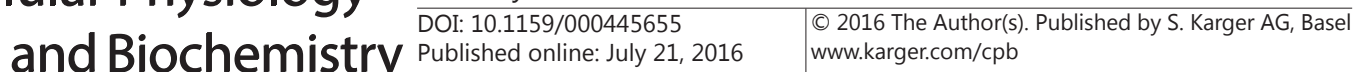

Al Mamun Bhuyan et al.: Dolutegravir-Induced Eryptosis

\section{Acknowledgements}

The authors acknowledge the meticulous preparation of the manuscript by Tanja Loch. The study was supported by the Deutsche Forschungsgemeinschaft and Open Access Publishing Fund of Tuebingen University.

\section{Disclosure Statement}

The authors state that they have no conflict of interest.

\section{References}

1 Bailly F, Cotelle P: The preclinical discovery and development of dolutegravir for the treatment of HIV. Expert Opin Drug Discov 2015;10:1243-1253.

2 Ballantyne AD, Perry CM: Dolutegravir: first global approval. Drugs 2013;73:1627-1637.

3 Blanco Arevalo JL, Whitlock GG: Dolutegravir: an exciting new kid on the block. Expert Opin Pharmacother 2014;15:573-582.

4 Cottrell ML, Hadzic T, Kashuba AD: Clinical pharmacokinetic, pharmacodynamic and drug-interaction profile of the integrase inhibitor dolutegravir. Clin Pharmacokinet 2013;52:981-994.

5 Cruciani M, Malena M: Combination dolutegravir-abacavir-lamivudine in the management of HIV/AIDS: clinical utility and patient considerations. Patient Prefer Adherence 2015;9:299-310.

6 Curtis L, Nichols G, Stainsby C, Lim J, Aylott A, Wynne B, Clark A, Bloch M, Maechler G, Martin-Carpenter L, Raffi F, Min S: Dolutegravir: clinical and laboratory safety in integrase inhibitor-naive patients. HIV Clin Trials 2014;15:199-208.

7 Fantauzzi A, Mezzaroma I: Dolutegravir: clinical efficacy and role in HIV therapy. Ther Adv Chronic Dis 2014;5:164-177.

8 Fantauzzi A, Turriziani 0, Mezzaroma I: Potential benefit of dolutegravir once daily: efficacy and safety. HIV AIDS (Auckl) 2013;5:29-40.

9 Fernandez-Montero JV, Barreiro P, Labarga P, De Mendoza C, Soriano V: Dolutegravir, abacavir and lamivudine as HIV therapy. Expert Opin Pharmacother 2014;15:1051-1057.

10 Greig SL, Deeks ED: Abacavir/dolutegravir/lamivudine single-tablet regimen: a review of its use in HIV-1 infection. Drugs 2015;75:503-514.

11 Kandel CE, Walmsley SL: Dolutegravir - a review of the pharmacology, efficacy, and safety in the treatment of HIV. Drug Des Devel Ther 2015;9:3547-3555.

12 Katlama C, Murphy R: Dolutegravir for the treatment of HIV. Expert Opin Investig Drugs 2012;21:523-530.

13 Keeshin SW, Feinberg J: Evaluation of dolutegravir safety for the treatment of HIV-1. Expert Opin Drug Saf 2015;14:141-147.

14 Llibre JM, Pulido F, Garcia F, Garcia Deltoro M, Blanco JL, Delgado R: Genetic barrier to resistance for dolutegravir. AIDS Rev 2015;17:56-64.

15 McCormack PL: Dolutegravir: a review of its use in the management of HIV-1 infection in adolescents and adults. Drugs 2014;74:1241-1252.

16 Mesplede T, Wainberg MA: Is resistance to dolutegravir possible when this drug is used in first-line therapy? Viruses 2014;6:3377-3385.

17 Miller MM, Liedtke MD, Lockhart SM, Rathbun RC: The role of dolutegravir in the management of HIV infection. Infect Drug Resist 2015;8:19-29.

18 Narang BK, Grewal GK, Roy S, Bariwal J, Gupta MK, Rawal RK: A novel integrase targeting agent to explore the future prospective of HIV eradication: dolutegravir. Curr HIV Res 2014;12:325-338.

19 Osterholzer DA, Goldman M: Dolutegravir: a next-generation integrase inhibitor for treatment of HIV infection. Clin Infect Dis 2014;59:265-271.

20 Rathbun RC, Lockhart SM, Miller MM, Liedtke MD: Dolutegravir, a second-generation integrase inhibitor for the treatment of HIV-1 infection. Ann Pharmacother 2014;48:395-403. 


\section{Cellular Physiology Cell Physiol Biochem 2016;39:639-650 \begin{tabular}{l|l|l|}
\hline DOI: 10.1159/000445655 & $\begin{array}{l}\text { C) 2016 The Author(s). Published by S. Karger AG, Basel } \\
\text { www.karger.com/cpb }\end{array}$
\end{tabular} \\ Al Mamun Bhuyan et al.: Dolutegravir-Induced Eryptosis}

21 Shah BM, Schafer JJ, Desimone JA Jr: Dolutegravir: a new integrase strand transfer inhibitor for the treatment of HIV. Pharmacotherapy 2014;34:506-520.

22 Taha H, Das A, Das S: Clinical effectiveness of dolutegravir in the treatment of HIV/AIDS. Infect Drug Resist 2015;8:339-352.

23 Wainberg MA, Han YS: Will drug resistance against dolutegravir in initial therapy ever occur? Front Pharmacol 2015;6:90.

24 Wu G, Abraham T, Saad N: Dolutegravir for the treatment of adult patients with HIV-1 infection. Expert Rev Anti Infect Ther 2014;12:535-544.

25 Bollen P, Reiss P, Schapiro J, Burger D: Clinical pharmacokinetics and pharmacodynamics of dolutegravir used as a single tablet regimen for the treatment of HIV-1 infection. Expert Opin Drug Saf 2015;14:14571472.

26 Patel DA, Snedecor SJ, Tang WY, Sudharshan L, Lim JW, Cuffe R, Pulgar S, Gilchrist KA, Camejo RR, Stephens J, Nichols G: 48-week efficacy and safety of dolutegravir relative to commonly used third agents in treatment-naive HIV-1-infected patients: a systematic review and network meta-analysis. PLoS One 2014;9:e105653.

27 Wagner N, Wyler-Lazarevic CA, Yerly S, Samer C, Peytavin G, Posfay-Barbe KM, Calmy A, Ambrosioni J: Dolutegravir-based antiretroviral therapy in a severely overweight child with a multidrug-resistant human immunodeficiency virus infection. A case report and review. New Microbes New Infect 2015;6:1-4.

28 Min S, Song I, Borland J, Chen S, Lou Y, Fujiwara T, Piscitelli SC: Pharmacokinetics and safety of S/ GSK1349572, a next-generation HIV integrase inhibitor, in healthy volunteers. Antimicrob Agents Chemother 2010;54:254-258.

29 Alzoubi K, Calabròa S, Bissinger R, Abed M, Faggio C, Lang F: Stimulation of Suicidal Erythrocyte Death by Artesunate. Cell Physiol Biochem 2014;34:2232-2244.

30 Alzoubi K, Egler J, Abed M, Lang F: Enhanced Eryptosis Following Auranofin Exposure. Cell Physiol Biochem 2015;37:1018-1028.

31 Arnold M, Bissinger R, Lang F: Mitoxantrone-induced suicidal erythrocyte death. Cell Physiol Biochem 2014;34:1756-1767.

32 Arnold M, Lang E, Modicano P, Bissinger R, Faggio C, Abed M, Lang F: Effect of nitazoxanide on erythrocytes. Basic Clin Pharmacol Toxicol 2014;114:421-426.

33 Bouguerra G, Bissinger R, Abbes S, Lang F: Stimulation of Eryptosis by Narasin. Cell Physiol Biochem 2015;37:1807-1816.

34 Bouguerra G, Bissinger R, Abbes S, Lang F: Zopolrestat Induced Suicidal Death of Human Erythrocytes. Cell Physiol Biochem 2015;37:1537-1546.

35 Bissinger R, Fischer S, Jilani K, Lang F: Stimulation of Erythrocyte Death by Phloretin. Cell Physiol Biochem 2014;34:2256-2265.

36 Bissinger R, Lupescu A, Zelenak C, Jilani K, Lang F: Stimulation of eryptosis by cryptotanshinone. Cell Physiol Biochem 2014;34:432-442.

37 Bouguerra G, Aljanadi O, Bissinger R, Abbes S, Lang F: Embelin-Induced Phosphatidylserine Translocation in the Erythrocyte Cell Membrane. Cell Physiol Biochem 2015;37:1629-1640.

38 Fazio A, Briglia M, Faggio C, Alzoubi K, Lang F: Stimulation of Suicidal Erythrocyte Death by Garcinol. Cell Physiol Biochem 2015;37:805-815.

39 Briglia M, Fazio A, Signoretto E, Faggio C, Lang F: Edelfosine Induced Suicidal Death of Human Erythrocytes. Cell Physiol Biochem 2015;37:2221-2230.

40 Calabro S, Alzoubi K, Faggio C, Laufer S, Lang F: Triggering of Suicidal Erythrocyte Death Following Boswellic Acid Exposure. Cell Physiol Biochem 2015;37:131-142.

41 Egler J, Lang F: Licochalcone A Induced Suicidal Death of Human Erythrocytes. Cell Physiol Biochem 2015;37:2060-2070.

42 Faggio C, Alzoubi K, Calabro S, Lang F: Stimulation of suicidal erythrocyte death by PRIMA-1. Cell Physiol Biochem 2015;35:529-540.

43 Jacobi J, Lang E, Bissinger R, Frauenfeld L, Modicano P, Faggio C, Abed M, Lang F: Stimulation of erythrocyte cell membrane scrambling by mitotane. Cell Physiol Biochem 2014;33:1516-1526.

44 Lang E, Jilani K, Bissinger R, Rexhepaj R, Zelenak C, Lupescu A, Lang F, Qadri SM: Vitamin D-Rich Diet in Mice Modulates Erythrocyte Survival. Kidney Blood Press Res 2015;40:403-412. 


\section{Cellular Physiology Cell Physiol Biochem 2016;39:639-650 \begin{tabular}{l|l|l|}
\hline DOI: 10.1159/000445655 & $\begin{array}{l}\text { C) 2016 The Author(s). Published by S. Karger AG, Basel } \\
\text { www.karger.com/cpb }\end{array}$
\end{tabular} \\ Al Mamun Bhuyan et al.: Dolutegravir-Induced Eryptosis}

45 Officioso A, Alzoubi K, Manna C, Lang F: Clofazimine Induced Suicidal Death of Human Erythrocytes. Cell Physiol Biochem 2015;37:331-341.

46 Lupescu A, Bissinger R, Goebel T, Salker MS, Alzoubi K, Liu G, Chirigiu L, Mack AF, Qadri SM, Lang F: Enhanced suicidal erythrocyte death contributing to anemia in the elderly. Cell Physiol Biochem 2015;36:773-783.

47 Lupescu A, Bissinger R, Herrmann T, Oswald G, Jilani K, Lang F: Induction of suicidal erythrocyte death by novobiocin. Cell Physiol Biochem 2014;33:670-680.

48 Lupescu A, Bissinger R, Warsi J, Jilani K, Lang F: Stimulation of erythrocyte cell membrane scrambling by gedunin. Cell Physiol Biochem 2014;33:1838-1848.

49 Malik A, Bissinger R, Calabro S, Faggio C, Jilani K, Lang F: Aristolochic Acid Induced Suicidal Erythrocyte Death. Kidney Blood Press Res 2014;39:408-419.

50 Oswald G, Alzoubi K, Abed M, Lang F: Stimulation of suicidal erythrocyte death by ribavirin. Basic Clin Pharmacol Toxicol 2014;114:311-317.

51 Peter T, Bissinger R, Enkel S, Alzoubi K, Oswald G, Lang F: Programmed erythrocyte death following in vitro Treosulfan treatment. Cell Physiol Biochem 2015;35:1372-1380.

52 Stockinger K, Bissinger R, Bouguerra G, Abbes S, Lang F: Enhanced Eryptosis Following Exposure to Carnosic Acid. Cell Physiol Biochem 2015;37:1779-1791.

53 Tesoriere L, Attanzio A, Allegra M, Cilla A, Gentile C, Livrea MA: Oxysterol mixture in hypercholesterolemiarelevant proportion causes oxidative stress-dependent eryptosis. Cell Physiol Biochem 2014;34:10751089.

54 Waibel S, Bissinger R, Bouguerra G, Abbes S, Lang F: Saquinavir Induced Suicidal Death of Human Erythrocytes. Cell Physiol Biochem 2015;37:1973-1982.

55 Zierle J, Bissinger R, Egler J, Lang F: Lapatinib Induced Suicidal Death of Human Erythrocytes. Cell Physiol Biochem 2015;37:2275-2287.

56 Lang E, Lang F: Mechanisms and pathophysiological significance of eryptosis, the suicidal erythrocyte death. Semin Cell Dev Biol 2015;39:35-42.

57 Bissinger R, Bouguerra G, Al Mamun Bhuyan A, Waibel S, Abbes S, Lang F: Efavirenz Induced Suicidal Death of Human Erythrocytes. Cell Physiol Biochem 2015;37:2496-2507.

58 Bissinger R, Waibel S, Bouguerra G, Al Mamun Bhuyan A, Abbes S, Lang F: Enhanced Eryptosis Following Exposure to Lopinavir. Cell Physiol Biochem 2015;37:2486-2495.

59 Briglia M, Calabro S, Signoretto E, Alzoubi K, Laufer S, Faggio C, Lang F: Fucoxanthin Induced Suicidal Death of Human Erythrocytes. Cell Physiol Biochem 2015;37:2464-2475.

60 Briglia M, Fazio A, Faggio C, Lang F: Triggering of Suicidal Erythrocyte Death by Zosuquidar. Cell Physiol Biochem 2015;37:2355-2365.

61 Fazio A, Briglia M, Faggio C, Alzoubi K, Lang F: Oxaliplatin Induced Suicidal Death of Human Erythrocytes. Cell Physiol Biochem 2015;37:2393-2404.

62 Macczak A, Cyrkler M, Bukowska B, Michalowicz J: Eryptosis-inducing activity of bisphenol A and its analogs in human red blood cells (in vitro study). J Hazard Mater 2016;307:328-335.

63 Officioso A, Alzoubi K, Lang F, Manna C: Hydroxytyrosol inhibits phosphatidylserine exposure and suicidal death induced by mercury in human erythrocytes: Possible involvement of the glutathione pathway. Food Chem Toxicol 2016;89:47-53.

64 Officioso A, Manna C, Alzoubi K, Lang F: Bromfenvinphos induced suicidal death of human erythrocytes. Pestic Biochem Physiol 2016;126:58-63.

65 Qadri SM, Donkor DA, Bhakta V, Eltringham-Smith LJ, Dwivedi DJ, Moore JC, Pepler L, Ivetic N, Nazi I, Fox-Robichaud AE, Liaw PC, Sheffield WP: Phosphatidylserine externalization and procoagulant activation of erythrocytes induced by Pseudomonas aeruginosa virulence factor pyocyanin. J Cell Mol Med 2016;10.1111/jcmm.12778

66 Zierle J, Bissinger R, Bouguerra G, Abbes S, Lang F: Triggering of Suicidal Erythrocyte Death by Regorafenib. Cell Physiol Biochem 2016;38:160-172.

67 Pagano M, Faggio C: The use of erythrocyte fragility to assess xenobiotic cytotoxicity. Cell Biochem Funct 2015;33:351-355.

68 Ran Q Xiang Y, Liu Y, Xiang L, Li F, Deng X, Xiao Y, Chen L, Chen L, Li Z: Eryptosis Indices as a Novel Predictive Parameter for Biocompatibility of Fe304 Magnetic Nanoparticles on Erythrocytes. Sci Rep 2015;5:16209. 


\section{Cellular Physiology Cell Physiol Biochem 2016;39:639-650

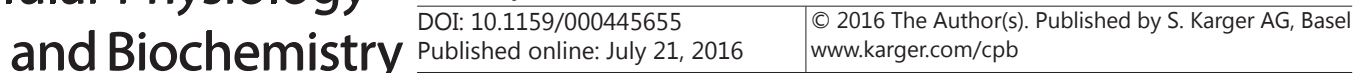 \\ Al Mamun Bhuyan et al.: Dolutegravir-Induced Eryptosis}

69 Bissinger R, Al Mamun Bhuyan A, Signoretto E, Lang F: Stimulating Effect of Elvitegravir on Suicidal Erythrocyte Death. Cell Physiol Biochem 2016;38:1111-1120.

70 Lupescu A, Bissinger R, Jilani K, Lang F: In vitro induction of erythrocyte phosphatidylserine translocation by the natural naphthoquinone shikonin. Toxins (Basel) 2014;6:1559-1574.

71 Lang PA, Kaiser S, Myssina S, Wieder T, Lang F, Huber SM: Role of Ca2+-activated K+ channels in human erythrocyte apoptosis. Am J Physiol Cell Physiol 2003;285:C1553-C1560.

72 Abed M, Towhid ST, Mia S, Pakladok T, Alesutan I, Borst O, Gawaz M, Gulbins E, Lang F: Sphingomyelinaseinduced adhesion of eryptotic erythrocytes to endothelial cells. Am J Physiol Cell Physiol 2012;303:C991999.

73 Kucherenko YV, Bernhardt I: Natural antioxidants improve red blood cell "survival" in non-leukoreduced blood samples. Cell Physiol Biochem 2015;35:2055-2068.

74 Zidova Z, Kapralova K, Koralkova P, Mojzikova R, Dolezal D, Divoky V, Horvathova M: DMT1-mutant erythrocytes have shortened life span, accelerated glycolysis and increased oxidative stress. Cell Physiol Biochem 2014;34:2221-2231.

75 Lau IP, Chen H, Wang J, Ong HC, Leung KC, Ho HP, Kong SK: In vitro effect of CTAB- and PEG-coated gold nanorods on the induction of eryptosis/erythroptosis in human erythrocytes. Nanotoxicology 2012;6:847856.

76 Maellaro E, Leoncini S, Moretti D, Del Bello B, Tanganelli I, De Felice C, Ciccoli L: Erythrocyte caspase-3 activation and oxidative imbalance in erythrocytes and in plasma of type 2 diabetic patients. Acta Diabetol 2013;50:489-495.

77 Lang E, Zelenak C, Eberhard M, Bissinger R, Rotte A, Ghashghaeinia M, Lupescu A, Lang F, Qadri SM: Impact of cyclin-dependent kinase CDK4 inhibition on eryptosis. Cell Physiol Biochem 2015;37:1178-1186.

78 Lang E, Bissinger R, Fajol A, Salker MS, Singh Y, Zelenak C, Ghashghaeinia M, Gu S, Jilani K, Lupescu A, Reyskens KM, Ackermann TF, Foller M, Schleicher E, Sheffield WP, Arthur JS, Lang F, Qadri SM: Accelerated apoptotic death and in vivo turnover of erythrocytes in mice lacking functional mitogen- and stressactivated kinase MSK1/2. Sci Rep 2015;5:17316.

79 Harrison HE, Bunting H, Ordway NK, Albrink WS: The Pathogenesis of the Renal Injury Produced in the Dog by Hemoglobin or Methemoglobin. J Exp Med 1947;86:339-356.

80 Borst O, Abed M, Alesutan I, Towhid ST, Qadri SM, Foller M, Gawaz M, Lang F: Dynamic adhesion of eryptotic erythrocytes to endothelial cells via CXCL16/SR-PSOX. Am J Physiol Cell Physiol 2012;302:C644-C651.

81 Andrews DA, Low PS: Role of red blood cells in thrombosis. Curr Opin Hematol 1999;6:76-82.

82 Chung SM, Bae ON, Lim KM, Noh JY, Lee MY, Jung YS, Chung JH: Lysophosphatidic acid induces thrombogenic activity through phosphatidylserine exposure and procoagulant microvesicle generation in human erythrocytes. Arterioscler Thromb Vasc Biol 2007;27:414-421.

83 Zwaal RF, Comfurius P, Bevers EM: Surface exposure of phosphatidylserine in pathological cells. Cell Mol Life Sci 2005;62:971-988.

84 Closse C, Dachary-Prigent J, Boisseau MR: Phosphatidylserine-related adhesion of human erythrocytes to vascular endothelium. Br J Haematol 1999;107:300-302.

85 Gallagher PG, Chang SH, Rettig MP, Neely JE, Hillery CA, Smith BD, Low PS: Altered erythrocyte endothelial adherence and membrane phospholipid asymmetry in hereditary hydrocytosis. Blood 2003;101:46254627.

86 Pandolfi A, Di Pietro N, Sirolli V, Giardinelli A, Di Silvestre S, Amoroso L, Di Tomo P, Capani F, Consoli A, Bonomini M: Mechanisms of uremic erythrocyte-induced adhesion of human monocytes to cultured endothelial cells. J Cell Physiol 2007;213:699-709.

87 Wood BL, Gibson DF, Tait JF: Increased erythrocyte phosphatidylserine exposure in sickle cell disease: flowcytometric measurement and clinical associations. Blood 1996;88:1873-1880.

88 Abed M, Feger M, Alzoubi K, Pakladok T, Frauenfeld L, Geiger C, Towhid ST, Lang F: Sensitization of erythrocytes to suicidal erythrocyte death following water deprivation. Kidney Blood Press Res 2013;37:567-578.

89 Voelkl J, Alzoubi K, Mamar AK, Ahmed MS, Abed M, Lang F: Stimulation of suicidal erythrocyte death by increased extracellular phosphate concentrations. Kidney Blood Press Res 2013;38:42-51.

90 Abed M, Artunc F, Alzoubi K, Honisch S, Baumann D, Foller M, Lang F: Suicidal erythrocyte death in endstage renal disease. J Mol Med (Berl) 2014;92:871-879. 


\section{Cellular Physiology Cell Physiol Biochem 2016;39:639-650 \begin{tabular}{l|l|l} 
DOI: 10.1159/000445655 & $\begin{array}{l}\text { O 2016 The Author(s). Published by S. Karger AG, Basel } \\
\text { www.karger.com/cpb }\end{array}$ \\
and Biochemistry Published online: July 21, 2016 & Ans
\end{tabular}}

Al Mamun Bhuyan et al.: Dolutegravir-Induced Eryptosis

91 Ahmed MS, Langer H, Abed M, Voelkl J, Lang F: The uremic toxin acrolein promotes suicidal erythrocyte death. Kidney Blood Press Res 2013;37:158-167.

92 Polak-Jonkisz D, Purzyc L: Ca(2+) influx versus efflux during eryptosis in uremic erythrocytes. Blood Purif 2012;34:209-210; author reply 210.

93 Calderon-Salinas JV, Munoz-Reyes EG, Guerrero-Romero JF, Rodriguez-Moran M, Bracho-Riquelme RL, Carrera-Gracia MA, Quintanar-Escorza MA: Eryptosis and oxidative damage in type 2 diabetic mellitus patients with chronic kidney disease. Mol Cell Biochem 2011;357:171-179.

94 Lang PA, Beringer O, Nicolay JP, Amon O, Kempe DS, Hermle T, Attanasio P, Akel A, Schafer R, Friedrich B, Risler T, Baur M, Olbricht CJ, Zimmerhackl LB, Zipfel PF, Wieder T, Lang F: Suicidal death of erythrocytes in recurrent hemolytic uremic syndrome. J Mol Med (Berl) 2006;84:378-388.

95 Nicolay JP, Schneider J, Niemoeller OM, Artunc F, Portero-Otin M, Haik G Jr, Thornalley PJ, Schleicher E, Wieder T, Lang F: Stimulation of suicidal erythrocyte death by methylglyoxal. Cell Physiol Biochem 2006;18:223-232.

96 Lang E, Gatidis S, Freise NF, Bock H, Kubitz R, Lauermann C, Orth HM, Klindt C, Schuier M, Keitel V, Reich M, Liu G, Schmidt S, Xu HC, Qadri SM, Herebian D, Pandyra AA, Mayatepek E, Gulbins E, Lang F, Haussinger D, Lang KS, Foller M, Lang PA: Conjugated bilirubin triggers anemia by inducing erythrocyte death. Hepatology 2015;61:275-284.

97 Kempe DS, Akel A, Lang PA, Hermle T, Biswas R, Muresanu J, Friedrich B, Dreischer P, Wolz C, Schumacher U, Peschel A, Gotz F, Doring G, Wieder T, Gulbins E, Lang F: Suicidal erythrocyte death in sepsis. J Mol Med (Berl) 2007;85:273-281.

98 Lang PA, Schenck M, Nicolay JP, Becker JU, Kempe DS, Lupescu A, Koka S, Eisele K, Klarl BA, Rubben H, Schmid KW, Mann K, Hildenbrand S, Hefter H, Huber SM, Wieder T, Erhardt A, Haussinger D, Gulbins E, Lang F: Liver cell death and anemia in Wilson disease involve acid sphingomyelinase and ceramide. Nat Med 2007;13:164-170. 